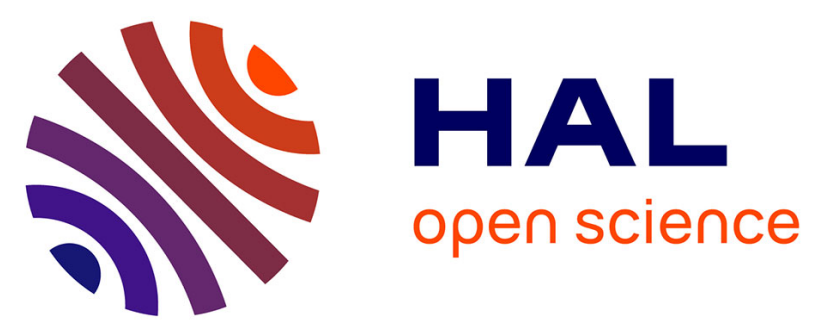

\title{
Sooted concretions: A new micro-chronological tool for high temporal resolution archaeology
}

Ségolène Vandevelde, Jacques Élie Brochier, Bruno Desachy, Christophe Petit, Ludovic Slimak

\section{- To cite this version:}

Ségolène Vandevelde, Jacques Élie Brochier, Bruno Desachy, Christophe Petit, Ludovic Slimak. Sooted concretions: A new micro-chronological tool for high temporal resolution archaeology. Quaternary International, 2018, Multidisciplinary approaches in the definition of high-resolution events to interpret past human behaviour: a new challenge in archaeology, 474 (B), pp.103-118. 10.1016/j.quaint.2017.10.031 . halshs-01688222

\section{HAL Id: halshs-01688222 \\ https://shs.hal.science/halshs-01688222}

Submitted on 6 Aug 2018

HAL is a multi-disciplinary open access archive for the deposit and dissemination of scientific research documents, whether they are published or not. The documents may come from teaching and research institutions in France or abroad, or from public or private research centers.
L'archive ouverte pluridisciplinaire HAL, est destinée au dépôt et à la diffusion de documents scientifiques de niveau recherche, publiés ou non, émanant des établissements d'enseignement et de recherche français ou étrangers, des laboratoires publics ou privés. 


\title{
Quaternary International
}

\author{
https://doi.org/10.1016/j.quaint.2017.10.031
}

\section{Sooted concretions: A new micro-chronological tool for high temporal resolution archaeology}

\author{
S. Vandevelde ${ }^{\text {a, }}{ }^{*}$, J.É. Brochier ${ }^{\text {b }}$, B. Desachy ${ }^{\text {a }}$, C. Petit ${ }^{\text {a }}$, L. Slimak ${ }^{\mathrm{c}}$ \\ a Université Paris 1 - Panthéon-Sorbonne, UMR 7041, ArScAn Équipe Archéologies environnementales, Maison de l'Archéologie et de l'Ethnologie (MAE), R. \\ Ginouvès, 21, allée de l'Université, 92023 Nanterre cedex, France \\ ${ }^{\mathrm{b}}$ Aix Marseille Univ (AMU), UMR 7269, LAMPEA, Maison méditerranéenne des sciences de l'homme, 5, rue du Château de l'Horloge, B.P. 647, 13 094 Aix-en- \\ Provence Cedex 2, France \\ ${ }^{\mathrm{C}}$ Université Toulouse - Jean Jaurès, UMR5608, Laboratoire TRACES, Maison de la Recherche Bât 26, 5, allée Antonio Machado, 31058 Toulouse Cedex, France
}

\section{A R T I C L E I N F O}

\section{Article history:}

Received 30 March 2017

Received in revised form

9 October 2017

Accepted 25 October 2017

Available online 13 November 2017

\section{Keywords:}

Micro-chronology

Carbonated crust

Soot

Palimpsest

Archaeological floor

Cumulative archaeological unit

\begin{abstract}
A B S T R A C T
Soot traces are witnesses of past human activities. They can sometimes be noticed on the walls and vaults of caves and rock shelters, sometimes also inside speleothems. These deposits resulting from anthropogenic fires prove to be a suitable material for micro-chronological studies. The microscopic analysis of parietal carbonated crusts of various ages, from Grotte Mandrin (Middle Palaeolithic from about 100 ka till early Upper Palaeolithic around $42 \mathrm{ka}$ BP) and from the Balma de la Margineda (late Upper Palaeolithic) shows that they have preserved the trace of multiple occupations. These latter can be linked to the archaeological units recognised on excavation field. The MNO (Minimum Number of Occupations) recorded at high temporal resolution for each archaeological level are usually high. These attest the cumulative nature of archaeological units and invite to rethink the following concepts of "archaeological floor" and "palimpsest" vis-à-vis spatial studies in caves and rock shelters. Each unit records a different number of occupations and shows its own rhythmicity in the succession of occupations. By retracing occupations chronicles of each archaeological level, possibility for studying mobility of passed human groups can also be raised.
\end{abstract}

\section{Introduction}

Identification of high-resolution events is sought for a long time in archaeological research. In fact, high temporal resolution is the only way to really study the social organisation of past human societies. That is why when a spatial organisation is visible in an archaeological layer, its necessarily cumulative nature is sometimes set aside to perform a palethnological study from an "occupation floor". Unfortunately, this approach is based on unproven and highly questionable premises. It obviously leads to errors and, even if it gives the illusion of a better understanding of the past, it is only a mirage.

Accepting the cumulative nature of the minimum archaeological units is nevertheless not a disadvantage. It is the starting point

\footnotetext{
* Corresponding author

E-mail addresses: segolene.vandevelde@univ-paris1.fr (S. Vandevelde), jacques. brochier@univ-amu.fr (J.É. Brochier), bruno.desachy@univ-paris1.fr (B. Desachy), christophe.petit@univ-paris1.fr (C. Petit), slimak@univ-tlse2.fr (L. Slimak).

of a whole field of research; by accepting this "restriction", a new problematic emerges: identification of high-resolution events, which are at the origin of the cumulative unit studied. Different perspectives and methods can (and should) meet, facing the same goal, which is to finally collect enough high temporal resolution data in order to efficiently interpret past human behaviour.

This paper intends to present one method among others to identify high-resolution events: the Fuliginochronology (the adjective "fuliginous" refers to the soot). Soot traces are witnesses of past human activities. They can sometimes be noticed on the walls and vaults of rock shelters and caves, sometimes also inside speleothems. These deposits resulting from anthropogenic fires prove to be a suitable material for micro-chronological study of human's occupations of a cave or a rock shelter. Concretions can keep track of many occupations, allowing the building of occupations chronicles of the site with high temporal resolution.

Mention of the presence of soot and/or charcoal on walls and vaults of rock shelters and caves or in speleothem formations is scarce in the archaeological literature. The majority of papers mentioning soot deposits are in fact focusing on the use of black 
pigments in rock art. Indeed, black pigments can come from, inter alia, soot or charcoal. See on this particular subject the $\mathrm{PhD}$ thesis of Emilie Chalmin (2006) on characterisation of manganese and use of black pigments during the Palaeolithic. Aside from artistic matters, a few cases have been reported around the world.

Mention of soot inclusion in speleothems is scarce. Yet any archaeological site located in a cave or rock-shelter and where the presence of hearth is attested has a high probability of including carbonaceous deposits in concretions. See Table 1 and Fig. 1 for examples.

This paper will focus on two rock shelters with parietal concretions trapping soot: the Balma de la Margineda in Andorra (Brochier, 1997, 1999; 2002, 2007; 2008) and the Grotte Mandrin in France (Vandevelde et al., 2017). The goal is not to present in detail the results obtained by study of sooted concretion at these two sites; they are already exposed in other papers (Brochier, 2008;

Table 1

List (non-exhaustive) of sites mentioned in literature with notified soot presence.

This worldwide review of sites shows that the two cases presented in the main text are not unique and that this type of study is applicable to many sites of different periods and in different climatic contexts. Of course, all these cases are very different and can't be interpreted in the same manner (the environmental and/or climatic conditions allowing the formation of concretions, seasonal precipitation of carbonates or not, conditions of recording and preservation of soot, type and age of concretions, nature of fires, etc.). Archaeological implications and anthropological interest also depend on the context.

\begin{tabular}{|c|c|c|c|c|c|c|c|}
\hline & Site & Country & $\begin{array}{l}\text { Soot on } \\
\text { walls } \\
\text { and or/ } \\
\text { vault }\end{array}$ & $\begin{array}{l}\text { soot inside } \\
\text { concretions }\end{array}$ & $\begin{array}{l}\text { Interest of the } \\
\text { soot }\end{array}$ & Notes & Bibliographical references \\
\hline Africa & Leshuta ol-pul & Kenya & $\mathrm{x}$ & & Modern & $\begin{array}{l}\text { Soot comes from cooking fires. Shelter used as a } \\
\text { meat-feasting site. Presence of rock art (Masai) }\end{array}$ & Gramly, 1975 \\
\hline \multirow[t]{11}{*}{ America } & Cueva del Diablo & Guatemala & $\mathrm{x}$ & & Modern & $\begin{array}{l}\text { Burnt offerings. Vault and back of the rock shelter are } \\
\text { covered with soot. Archaeological Mayan site, } \\
\text { Nowadays ceremonies }\end{array}$ & Ishihara-Brito and Guerra, 2012 \\
\hline & La Ventana & Guatemala & $\mathrm{x}$ & & Modern & $\begin{array}{l}\text { Soot from candles, burnt offerings. Archaeological } \\
\text { Mayan site, Nowadays ceremonies }\end{array}$ & Ishihara-Brito and Guerra, 2012 \\
\hline & $\begin{array}{l}\text { La Ventana } \\
\text { Campana }\end{array}$ & Guatemala & $\mathrm{x}$ & & Modern & $\begin{array}{l}\text { Niches whose walls and vault are covered with soot } \\
\text { in room } 1 \text {. In room } 2 \text { most of the blocks are covered } \\
\text { with soot. Archaeological Mayan site, Nowadays } \\
\text { ceremonies }\end{array}$ & Ishihara-Brito and Guerra, 2012 \\
\hline & $\begin{array}{l}\text { Esquipulas Cave } \\
\# 1 \text { (Cueva de las } \\
\text { Minas \#1) }\end{array}$ & Guatemala & $\mathrm{x}$ & & Archaeological & Candles in Mayan man-made caves & Brady and Veni 1992 \\
\hline & Jane's Cave & Bermuda & $\mathrm{x}$ & & Archaeological & Very old torch in speleothem & Gibbons, 2003 \\
\hline & Saltpeter cave & $\begin{array}{l}\text { USA, } \\
\text { Kentucky }\end{array}$ & $\mathrm{x}$ & & Modern & Saltpetre cave & Duncan, 1997 \\
\hline & Mammoth Cave & $\begin{array}{l}\text { USA, } \\
\text { Kentucky }\end{array}$ & $\mathrm{x}$ & & $\begin{array}{l}\text { Archaeological } \\
\text { and Modern }\end{array}$ & $\begin{array}{l}\text { Soot from Amerindian (Woodland) torches and } \\
\text { fireplaces; and soot accumulation from } 150 \text { years of } \\
\text { recent torches and kerosene lanterns. And Saltpetre } \\
\text { cave activity. }\end{array}$ & $\begin{array}{l}\text { Benington et al., 1962; } \\
\text { Baddeley, 1994; Duncan, } 1997\end{array}$ \\
\hline & Salts Cave & $\begin{array}{l}\text { USA, } \\
\text { Kentucky }\end{array}$ & $\mathrm{x}$ & $\mathrm{x}$ & Archaeological & $\begin{array}{l}\text { Amerindian torches and fireplaces (Woodland } \\
\text { culture) }\end{array}$ & $\begin{array}{l}\text { Benington et al., 1962; Watson } \\
\text { and Yarnell, } 1966\end{array}$ \\
\hline & Feather Cave & $\begin{array}{l}\text { USA, New } \\
\text { Mexico }\end{array}$ & $\mathrm{x}$ & & Archaeological & Cave used for ceremonies. Presence of rock art & Greer and Greer, 1997 \\
\hline & U-Bar Cave & $\begin{array}{l}\text { USA, New } \\
\text { Mexico }\end{array}$ & $\mathrm{x}$ & & Archaeological & $\begin{array}{l}\text { Burnt wall, torch smears, torch marks. Presence of } \\
\text { pictographs. }\end{array}$ & Greer and Greer, 1997 \\
\hline & $\begin{array}{l}\text { Tommy Tucker } \\
\text { Cave }\end{array}$ & $\begin{array}{l}\text { USA, } \\
\text { California }\end{array}$ & $\mathrm{x}$ & $\begin{array}{l}\text { highly probable. } \\
\text { Tufa and soot are } \\
\text { present on the } \\
\text { ceiling. }\end{array}$ & Archaeological & $\begin{array}{l}\text { Northern Paiute band called the Wadadökadö. } \\
\text { Presence of pictographs }\end{array}$ & Fenenga and Riddell, 1949 \\
\hline \multirow[t]{12}{*}{ Eurasia } & Einhornhöle & Germany & $\mathrm{x}$ & & Modern & Den of thieves & Mötefindt, 1914 \\
\hline & Sirgensteinhöhle & Germany & $\mathrm{x}$ & & Modern & Site used as fairgrounds & Striebel, 1996 \\
\hline & $\begin{array}{l}\text { Grotte de Han } \\
\text { sur Lesse }\end{array}$ & Belgium & & $\mathrm{x}$ & Modern & torches to light the tourists & $\begin{array}{l}\text { Genty et al., 1997b, 1998; } \\
\text { Verheyden et al., } 2006\end{array}$ \\
\hline & Bukovac Cave & Croatia & $\mathrm{x}$ & & $?$ & Lighting torches & Knežević and Žiković, 2011 \\
\hline & $\begin{array}{l}\text { Hajdova Hiža } \\
\text { Cave }\end{array}$ & Croatia & $\mathrm{x}$ & & $?$ & Lighting torches & Knežević and Žiković, 2011 \\
\hline & Pilar Ice Cave & Croatia & $\mathrm{x}$ & & $?$ & Lighting torches & Knežević and Žiković, 2011 \\
\hline & $\begin{array}{l}\text { Škodovnik Ice } \\
\text { Cave }\end{array}$ & Croatia & $\mathrm{x}$ & & $?$ & Lighting torches & Knežević and Žiković, 2011 \\
\hline & Zamet Cave & Croatia & $\mathrm{x}$ & & $?$ & Lighting torches & Knežević and Žiković, 2011 \\
\hline & $\begin{array}{l}\text { Cueva de } \\
\text { Corcheros }\end{array}$ & Spain & $\mathrm{x}$ & & Archaeological & $\begin{array}{l}\text { Ceiling completely blackened by fire. Presence of } \\
\text { rock art }\end{array}$ & Egaña et al., 2009 \\
\hline & Cueva Mayor & Spain & & $\mathrm{x}$ & Archaeological & Soot and charcoal in speleothems & $\begin{array}{l}\text { Martínez-Pillado et al., 2010, } \\
2014\end{array}$ \\
\hline & $\begin{array}{l}\text { Cueva Negra (del } \\
\text { Estrecho del Río } \\
\text { Quípa) }\end{array}$ & Spain & $\mathrm{x}$ & & Archaeological & Soot on inscriptions (rock art) & Stylow and Mayer, 1996 \\
\hline & $\begin{array}{l}\text { Grotte sur l'île } \\
\text { Ukonsaari }\end{array}$ & Finland & $\mathrm{x}$ & & $?$ & Sámi sacrificial site & Okkonen, 2007 \\
\hline
\end{tabular}


Table 1 (continued)

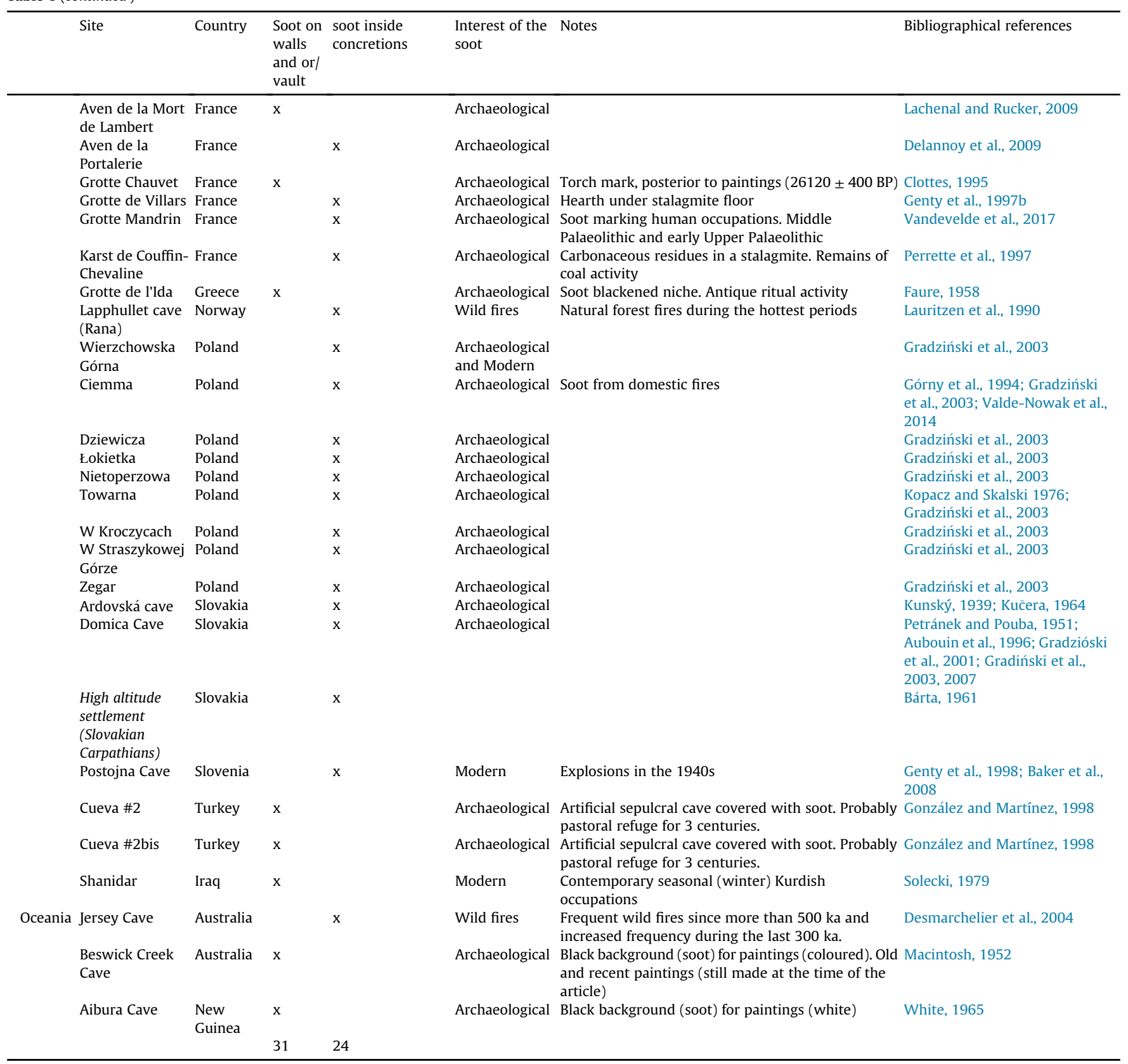

Vandevelde et al., 2017). This paper focuses more on the origins of the method, its adaptation for serial studies, on discussion of these results (only outlined here) and their implications (on spatial studies, conception of "palimpsest" and of "archaeological floor"). Will also be discussed the implications of high temporal resolution given by a new efficient micro-chronological tool on study of past societies (perspectives on mobility studies, etc.).

\section{Regional setting}

The Balma de la Margineda (Sant Julìa de Lòria, Andorra) is located at an altitude of $970 \mathrm{~m}$ in the Pyrenees, and the Grotte Mandrin (Malataverne, Drôme, France) is situated at an altitude of $245 \mathrm{~m}$ in the middle Rhone Valley (Fig. 2). They are both morphologically rock shelters overlooking a valley. The Balma de la Margineda is formed in schist and the Grotte Mandrin is formed in Barremo-Bedoulian limestone. Both are under Mediterranean influence and both are opened towards the North.

\section{Material and methods. Sooted concretions: a micro- chronological tool}

In these two sites, the sooted concretions observed can be considered as parietal stromatolithic constructions. They are covering the external surface of the clasts resulting from the mechanical disintegration of the walls and vaults. The clastic fragments constitute the major part of the filling of these rock shelters. The budding stromatolithic structure of the clasts coating shows 


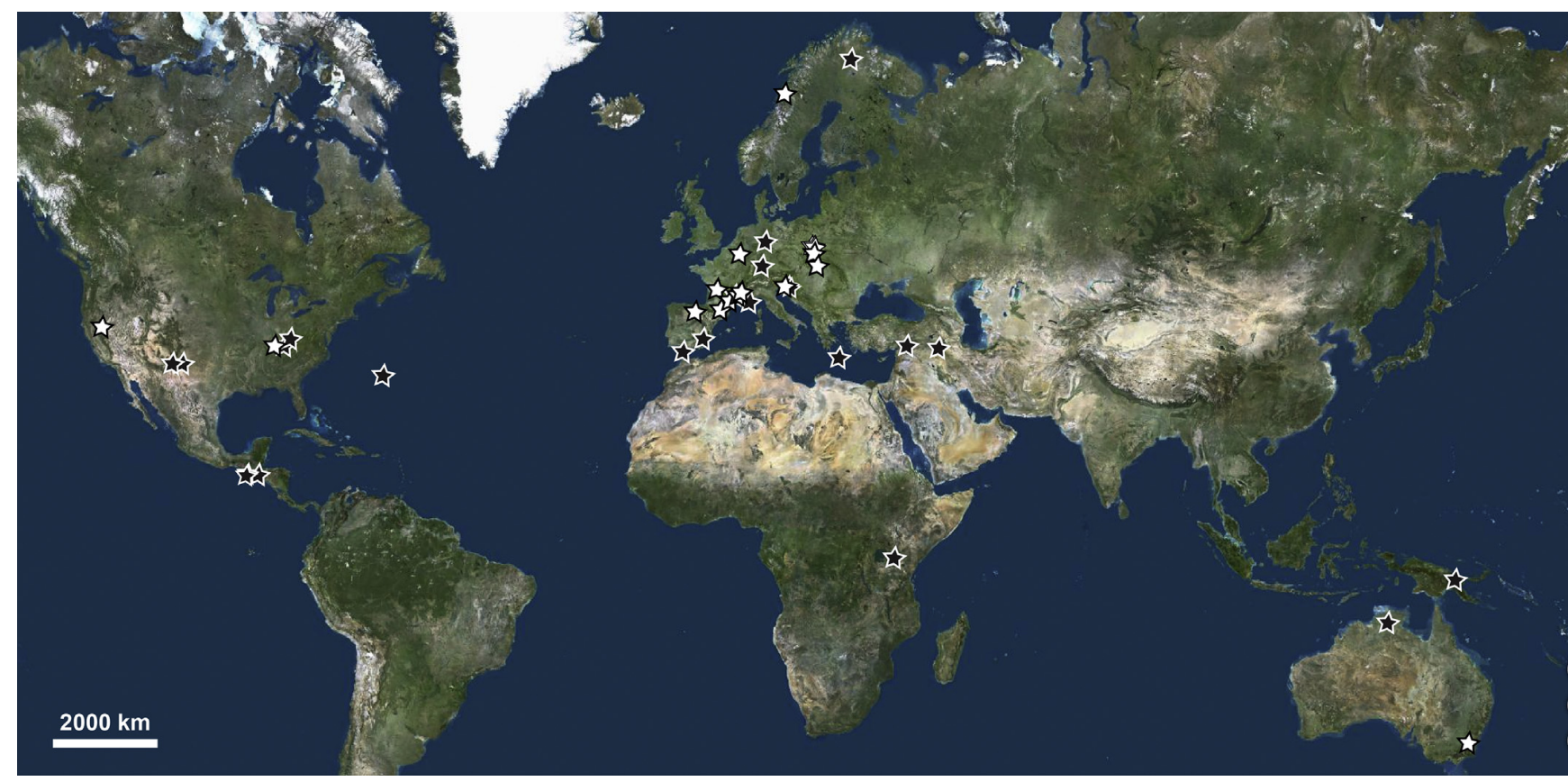

Fig. 1. Location of sites mentioned in literature with notified soot presence. Black stars rimmed with white: presence of soot on vault and walls of cave or rock shelter; White stars rimmed with black: presence of soot inside concretions.

the biochemical nature of their genesis; it depends on precipitation and more generally on the moisture, which conditions the activity of living organisms like algae, lichens and bacteria. The lamination of these concretions is conditioned by the seasonal hydrological variations, which lead to the formation of micritic or palisadic micro-sparitic laminae. White Porous Laminae (WPL, micrite) are white in reflected light, whereas Dark Compact Laminae (DCL, micro-sparite) appear dark in reflected light. A DCL-WPL doublet generally corresponds to an annual cycle for speleothems, with DCL being formed during periods of hydric excess and WPL when meteorological conditions are dryer (Genty et al., 1995; 1997a; Baker et al., 2008). This differentiation in the crystalline fabric appears when the seasons are marked regarding hydric conditions. The alternation of DCL/WPL is a cyclic phenomenon: it recurs periodically and according to the same process. In nature, seasonal, annual, or decennial ( 11 year sun-cycle) weather cycles could explain the DCL/WPL alternation. It is for this reason that we will speak of sub-annual to decennial temporal resolution in the text.

Black deposit can have several origins. At the Balma de la Margineda as at the Grotte Mandrin, no trace of manganese could be detected in the crusts by X-ray microprobe analysis. The possible confusion between a lamina enriched with iron oxides and a soot film can also easily be avoided by a simple observation in reflected light. In addition, micro-charcoals are sometimes trapped inside parietal crusts of the Grotte Mandrin. The black laminae in carbonated crusts are therefore composed of soot and possibly of charcoal particles trapped under carbonates veils. In other words, smoke deposits soot films on the walls and vaults of caves and shelters, as it can be seen in many caves and shelters used nowadays. These soot films are preserved in carbonated crusts under favourable circumstances: the carbonates must cement the soot quickly enough to preserve it. This means that the growth of the carbonated crust has to be active, at annual scale, during fire episodes.

Until now, the few studies that have been carried out on black laminae trapped in concretions have all concluded that these soot deposits are a very good marker of human presence. They may have been directly dated to identify the periods of use of a site (See e.g. the analyses in Domica cave, Petránek and Pouba, 1951; Gradziòski et al., 2001; Gradziński et al., 2003, 2007). The seasonal nature of occupations (e.g. Genty et al., 1997b; Verheyden et al., 2006; Martínez-Pillado et al., 2010, 2014) could also be clarified from the position of the films in the DCL-WPL. We have noticed that the study of these sooted concretions is not systematic, even when they are noticed. Issues about micro-chronology of the occupations are occasionally explored (e.g. seasonality of occupations). The link between archaeological deposit and speleothems is sometimes established (e.g. dating the soot or concretion in order to date an archaeological level). But these questions are never jointly developed. Excepting the two cases presented below, no study has been carried out on the construction of micro-chronological chronicles of the human frequentation of a rock shelter or a cave linked with the constitution of the archaeological deposits.

The micro-chronology refers to a high temporal resolution, from sub-annual to decennial; it can be compared to a "human life or ethnological timescale". In the two following cases, microstratigraphical observations are interpreted through a microchronological approach, which pretends to order the events on a time scale (floating) linked explicitly and reliably with time. The temporal resolution is known, controlled or precisely estimated. When laminated concretions are studied, the resolution is generally infra-annual thanks to the DCL/WPL pairs (Vandevelde et al., 2017).

We studied sooted parietal carbonated crusts from late Upper Palaeolithic at the Balma de la Margineda and from Middle Palaeolithic and early Upper Palaeolithic at the Grotte Mandrin, cemented in carbonated crusts covering the clasts that were collected in several sedimentary units of these two rock shelters. Microscopic observation of thin sections and/or polished sections made in the growth axis of the concretions shows that what could appear as a single black lamina to the naked eye or at low magnification (Fig. 3) usually resolves into a multitude of thin soot films a 

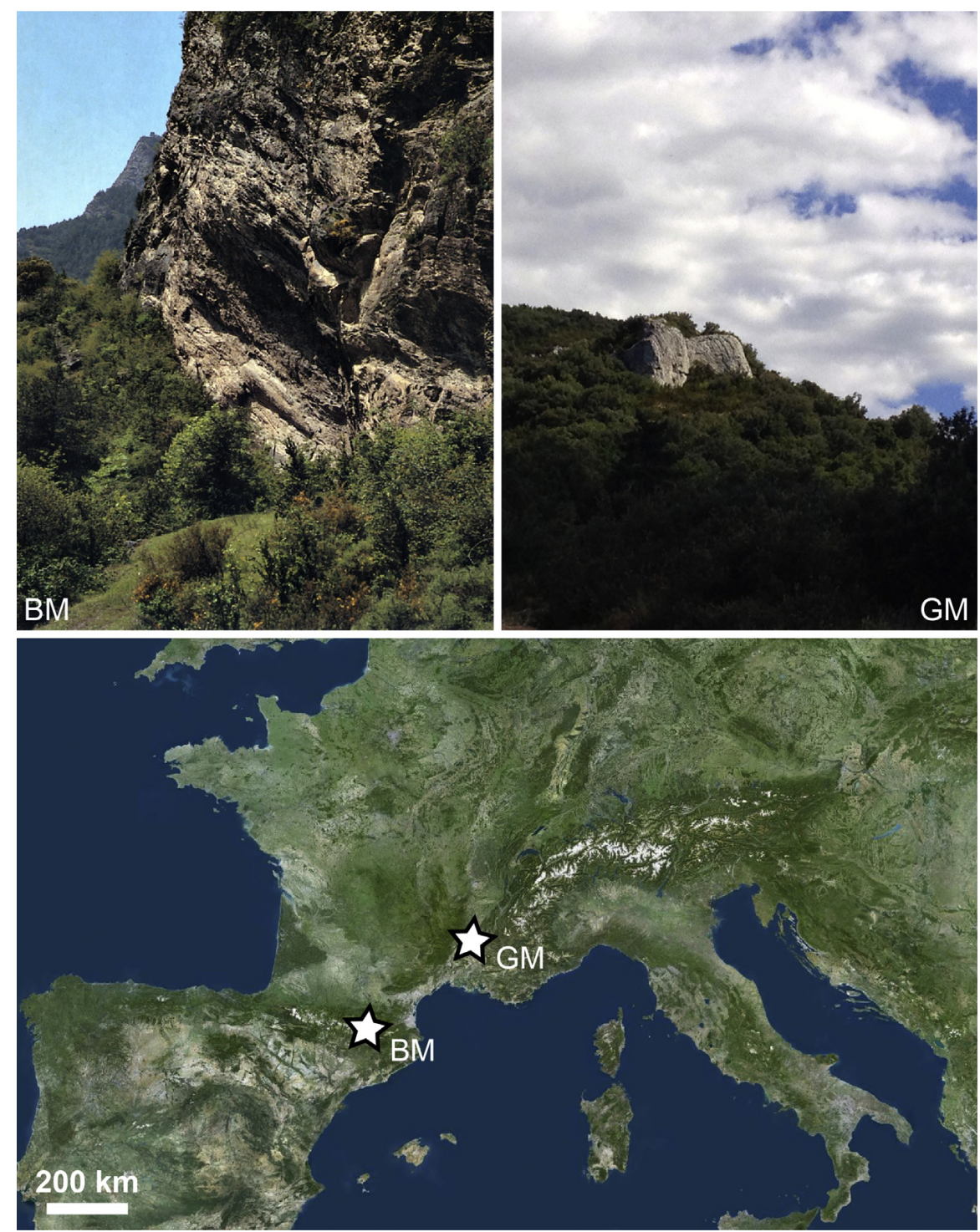

Fig. 2. Location of the Grotte Mandrin (Drôme, France) and the Balma de la Margineda (Andorra) sites. GM is located in the middle Rhône Valley on the left bank of the River; BM is situated in the Pyrenees.

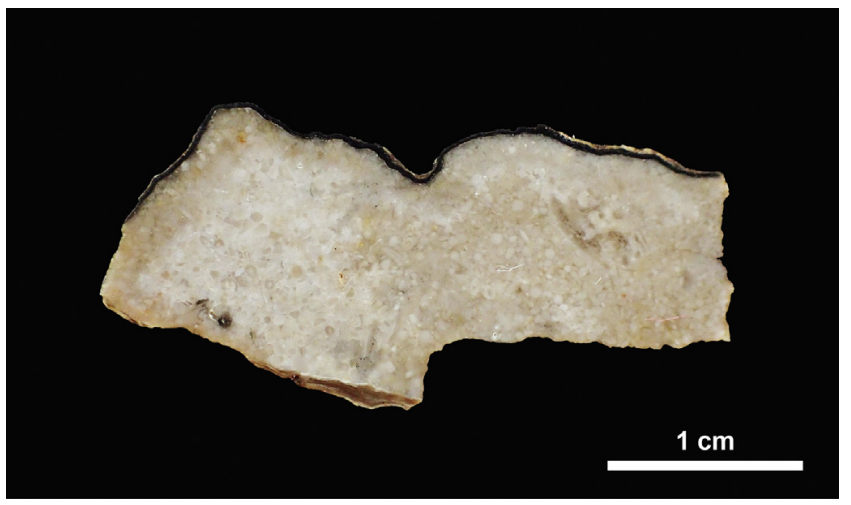

Fig. 3. Polished section of a clast (limestone platelet) from the Grotte Mandrin (B/C layer). Only a unique soot deposit appears to the naked eye. few micrometres thick (Fig. 4). These series of soot films are several witnesses of the numerous humans' occupations in the rock shelter. They are graphically documented in the form of "barcode" diagrams (Fig. 5) from photographs. On these diagrams, the black continuous lines represent the soot films and the space separating them corresponds to the thickness of carbonated laminae that are not stained by the soot, suggesting it crystallised during human absence. In each sedimentary unit, each sample analysed allows the construction of an individual sequence. By matching these different "barcodes" from the same sedimentary unit, it is possible to establish a synthetic sequence (Fig. 5) that documents all the corresponding human occupations. Thus, the count of the soot films per sedimentary unit allows obtaining of a Minimal Number of Occupations (MNO). It is found that it is generally impossible to match sequences recorded on fragments coming from two different layers by a set of expansion/contraction of the diagrams (Fig. 6). On contrary, it is possible to do this between samples from the same 


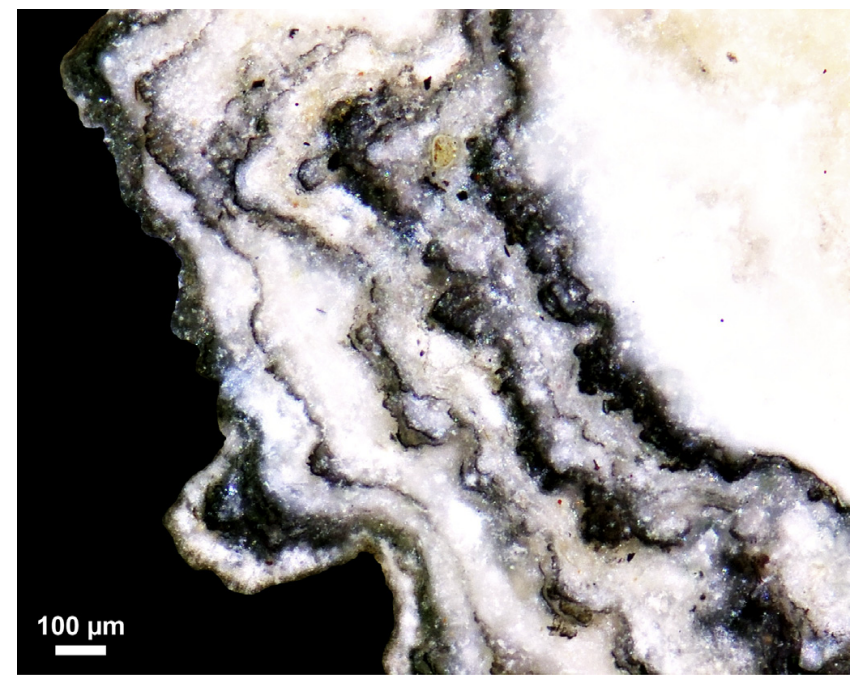

Fig. 4. Observation of sample E-123 at high magnification showing multiple soo deposits in the form of very thin black laminae. Grotte Mandrin, Layer E. Polished section, RL.

layer (Fig. 7). This shows, a posteriori, that the crusts' growth rates, although different at each point of the walls/vault, follow the same evolutions. The micro-chronology of the successive occupations of caves or rock shelters, including the notions of rhythmicity of occupations and of phases of occupation that can be defined as sets of occupations separated by long hiatus or differentiated by different occupational rhythms, becomes accessible with a resolution, which can be annual in the most favourable cases.

Note that the term "Minimal" (in MNO) is used here for three reasons: first, because two occupations close in time should only leave one soot film on the vault depending on the rate of carbonate accretion; second, because occupations without fire are possible; and third because it refers to the number of soot films recorded and preserved inside the concretion. Note also that a sample of limited size of sooted limestone platelets is studied. A larger sample could provide higher MNO.

Concerning recording of soot films, note that all the fragments do not bear blackened carbonated coating. What is important is that if they include soot, it means that they have recorded the fire event. They were therefore relatively close to the location of the fireplace on the vault during the formation of the crust. In the particular case of Grotte Mandrin, the principal fireplace is always situated at the same location, in the middle of the porch, at least from layer $\mathrm{E}$ to $\mathrm{B}$. This suggests that when a clast is blackened by an episode of fire, it will also be blackened during the next fires. Interpretations would not be the same if the site contained several fireplaces but here, absence of soot in the coating strongly suggests human absence in the site.

Other factors play a role in recording and preservation of soot: the surface of the parietal carbonate crust can be water saturated especially during wet season and a well-developed cover of epilithic organisms can also occur. At first sight, one would think that it could prevent the recording of soot and part of the combustion residues could also be washed down. However, actualistic observations and experimentation in Grotte Mandrin allows observation of this fixation phenomenon: the first soot particles deposited stick to the rock, and the soot particles that lay over the other soot particles can be washed down or blown up. That is why we can observe only thin black films impregnating the carbonates and not layers of soot with real thickness between layers of carbonates in Balma de la Margineda and Grotte Mandrin sites. Wind and water can remove a part of the soot deposit, but because of the carbonates asperities, a part of the soot sticks to the carbonated crust. Furthermore, the high moisture level in some locations actually enhances the fixation of soot, up to a certain point: note that in tropical areas, soot deposited on vault and/or walls of rock shelters can be completely washed down by strong tropical rains (ethnographic observations by Pierre Pétrequin, personal communications). It is nevertheless not the case in the Grotte Mandrin, where the soot films are present indifferently inside DCL and WPL laminae. Meaning that they have been recorded in dry periods (WPL) as well as in periods of hydric access (DCL) and that they have been preserved in both cases.

\subsection{The method's origins. The Balma de la Margineda case}

To the best of our knowledge, the first application to archaeological problems was made from thin fragments of parietal stromatoliths covering schist platelets scattered in the tardiglacial deposits of a Pyrenean rock shelter: the Balma de la Margineda (Guilaine and Martzluff, 1995; Guilaine et al., 2008; Brochier, 1997, 1999; 2002, 2008). These fragments are thin, scarce and very small, always much smaller than one square centimetre. They justify on their own the meticulous observation of all the coarse elements extracted from voluminous sedimentary samples. Their high magnification observation in thin sections shows that the crusts are formed by alternate micritic and sparictic laminae (Fig. 8). These laminae form stromatolithic domes in some locations, where soot has been preferentially trapped and/or preserved (Fig. 9). Only micritic laminae have soot films on in this succession of numerous DCL-WPL doublets. The fragments collected in the few successive Azilian archaeological units (layers 9 to 7 ) exhibit such a similarity in the rhythms of occupation (absence or presence of soot film) that one must conclude there was a single secular period of concretioning, which represents part (or all) of the time corresponding to a single archaeological layer: layer 9 (Fig. 10).

The current local climatic characteristics and associated hydrological processes, largely conditioned by relief and snow cover, reinforce the annual character of the doublets. The Azilian archaeological layer (C9) thus appears as resulting from the accumulation of very numerous ( $\mathrm{N}>30$ ) annual occupations, sometimes consecutive, always at the same time of the year. Unlike the Grotte Mandrin case, soot films are not recorded indifferently inside DCL and WPL laminae; therefore there is no evidence that the soot films were not washed down during the wet periods on this particular site. To be able to conclude without ambiguity on the site occupation's dynamics, the micro-chronological data collected from sooted coatings had to be crossed with fauna data (Le Gall, 2008; Martin, 2008). The latter showed slaughtering of ibexes during the Capra ibex's mating season: fall / early winter, between the end of November and mid-January. Soot film position in DCL/ WPL doublets and faunal data in the Balma de la Margineda lead to the conclusions that the shelter was occupied only a few months in the year, regularly, always in the same season (at the time of ibexes' rut) by a group of hunters (-collectors); it was thus integrated into a site network connecting it with other sites. Beyond the archaeological information, the fundamental point is certainly the one that enforces to consider this archaeological layer as a composite and cumulative object. In other words, the synchronism of the different material witnesses collected in this unique Azilian layer (industry, fauna, and structures) is far from being assured. 


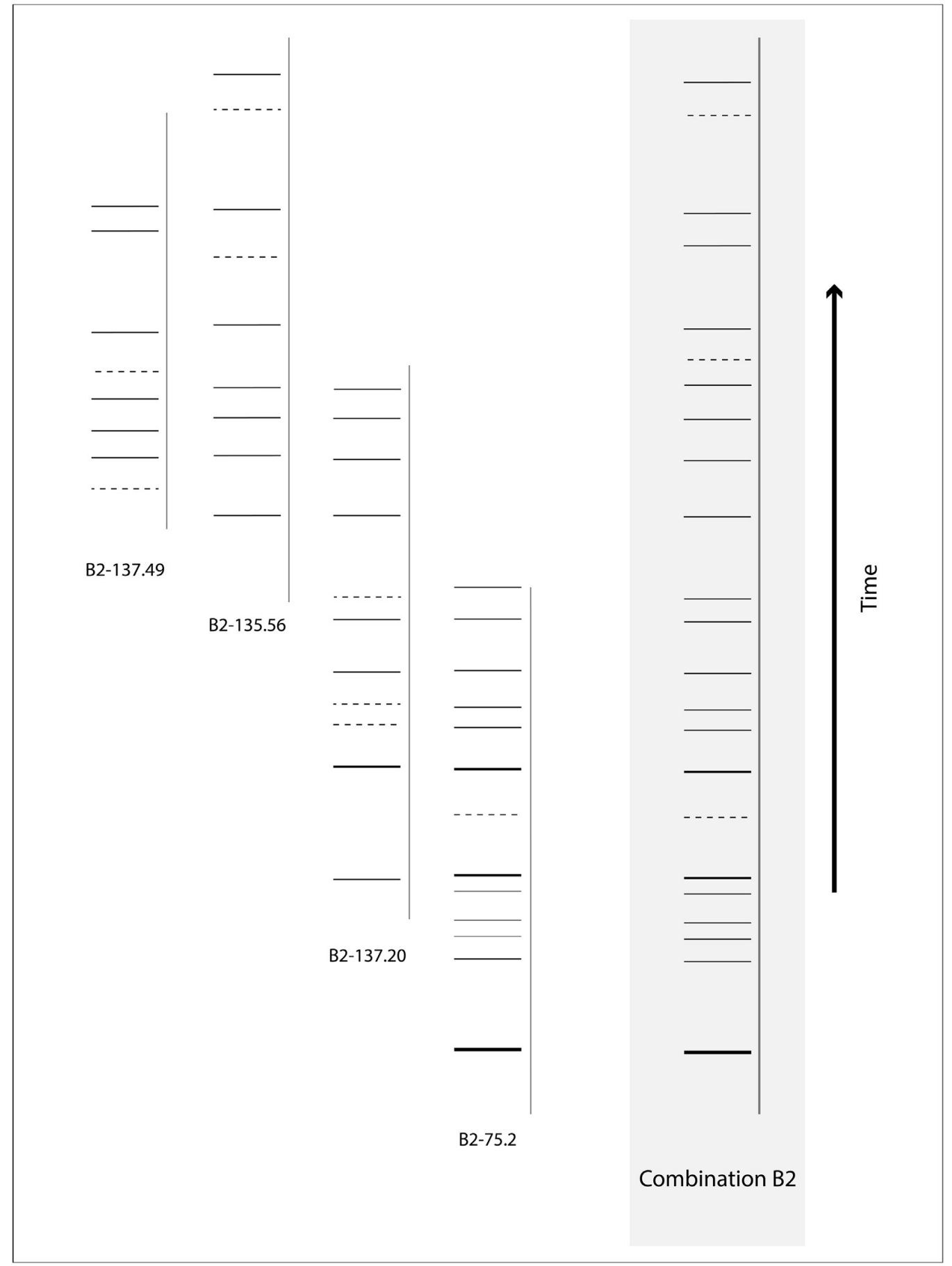

Fig. 5. Matching of the individual sequences from level B2's samples. Building of the occupations chronicle for level B2. Its overlap with B3 combination explains why there are here more films than the MNO reported in Table 5. For more details see Vandevelde et al. (2017). Continuous lines represent soot films, thicker lines represent particularly thick soot films (that can sometimes resolved in more than one soot film in other samples), and dotted lines symbolize uncertain soot deposits. The horizontal line represents the total thickness of the parietal carbonated crust of the sample. Denominations as "B2-137.49" are samples labels: "B" is for the sedimentary layer the sample comes from, specified by "2" for the archaeological level (B2), and 137.49 is the number of the sample.

\subsection{Adaptation to the Grotte Mandrin case and developments}

Excavations at the Grotte Mandrin began in 1990 and are led by Ludovic Slimak, Yves Giraud and Pascale Yvorra since 1998. The stratigraphy can be divided into ten sedimentary layers and thirteen archaeological levels. A sedimentary unit can contain one to several archaeological levels. From bottom to top, the first levels (J, I, H and G) are attributed to the Mousterian (from around $100 \mathrm{ka}$ at least). The overlying levels ( $\mathrm{F}$ to $\mathrm{B}$ ) can be divided into five cultural phases (homogeneous assemblages identified archaeologically) associated with the last Neanderthals and the first regional Homo sapiens: the Mousterian of Quina rhodanian type (layer F, Slimak, 


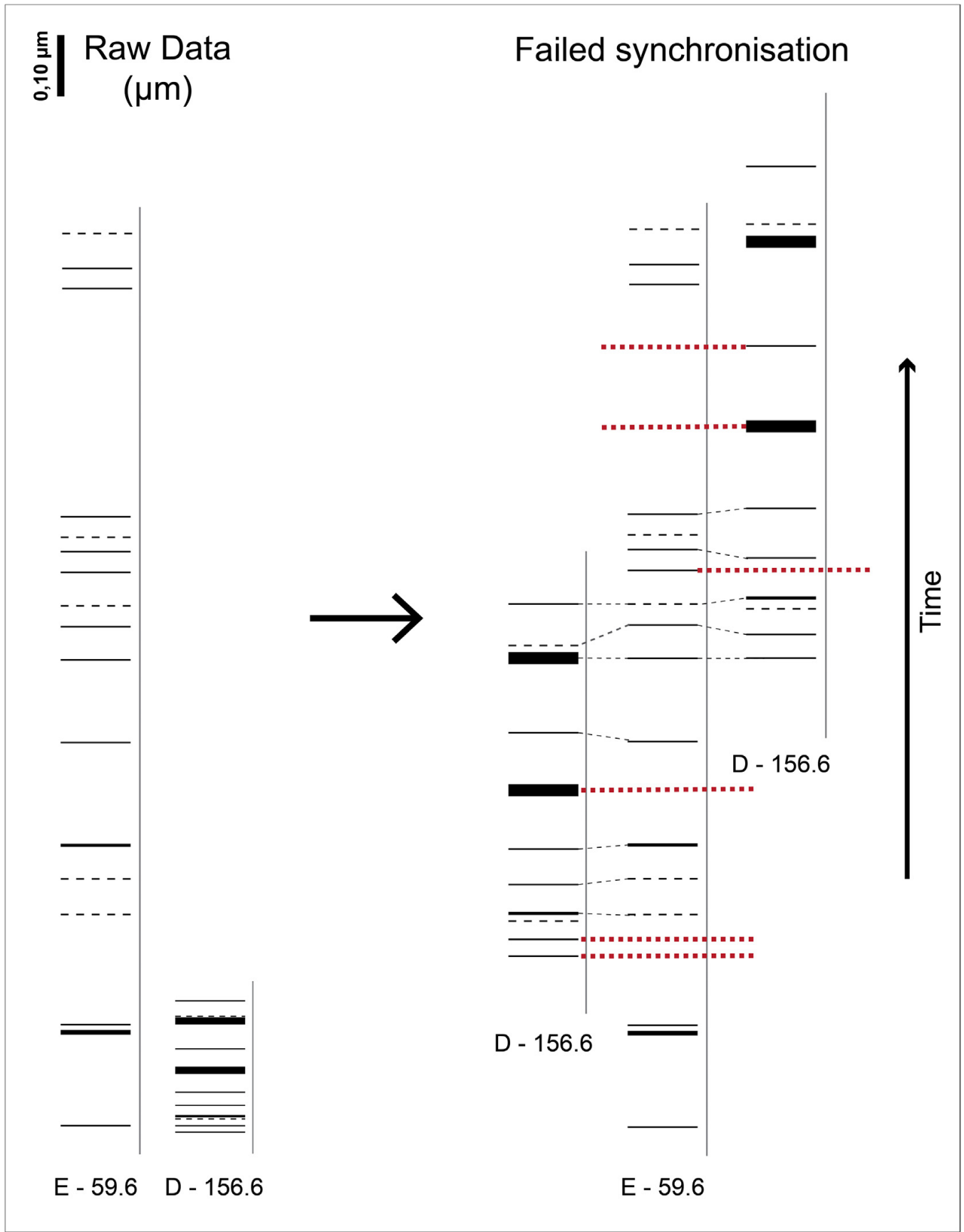

Fig. 6. Failure to synchronise individual sequences of two samples belonging to different sedimentary unit, Grotte Mandrin, layers E and D. Thick dotted lines (red in online version) show conflict of synchronisation. (For interpretation of the references to colour in this figure legend, the reader is referred to the web version of this article.)

1999), the initial Upper Palaeolithic Neronian culture (layer E, Slimak, 2008), the Post-Neronian I (layer D), the Post-Neronian II (levels B2, B3, B/C, C1 and C2) late groups of Mousterian tradition and the early Upper Palaeolithic Protoaurignacian culture (level B1, Slimak et al., 2006). These phases cover the end of the Middle Palaeolithic and the beginning of Upper Palaeolithic, from about 50 to $55 \mathrm{ka}$ to $42 \mathrm{ka}$ cal. BP (Higham et al., 2014; SOM pp. 34-38). At the top lays layer $\mathrm{A}$, a collective burial deposit with repeated cremations, dated from the Neolithic period (Slimak, 2004).

An adaptation of the micro-chronological method that was presented has been realised at this site. As for the Balma de la
Margineda, the aim was to establish a micro-chronology of human occupations from the study of sooted carbonated crusts, using in this case a large number of samples. Thus, observation of polished sections was preferred over systematic preparation of thin sections, very efficient but cumbersome technique. Ten samples (limestone platelets bearing sooted parietal carbonated crust) were selected randomly in each archaeological level for this serial study. For each sample studied, in reflected light at high magnification $(\times 50 ; \times 100 ; \times 200)$, photographs of the area where films are most numerous and most visible were taken. Measurement of distances between soot films and mapping of the raw data in "barcode" 


\section{్ㅚ Raw Data $(\mu \mathrm{m})$}

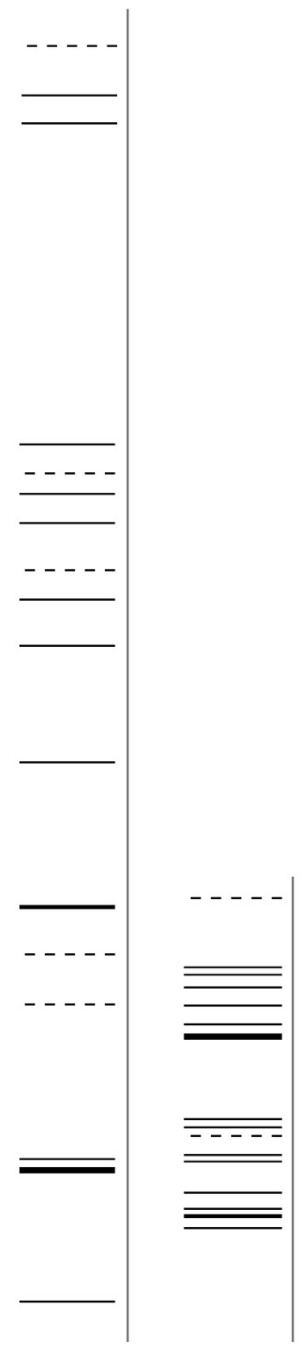

E-59.6 E- 100.26

\section{Synchronised barcode diagrams}

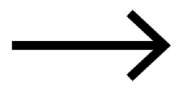

E - 59.6

Fig. 7. Synchronisation of individual sequences of two samples belonging to the same sedimentary unit, Grotte Mandrin, layer E. It is really the rhythms of succession of soot films that helps the matching (e.g. three films close to one another and then a big gap before two close films, etc.) more than the real thickness of "clean" carbonates between soot films.

diagrams were made from these photographs thanks to Datawald (G.L Conception) software. It is first dedicated to dendrochronology but it was adapted to our object of study. After verification of the diagrams produced under the microscope, graphic matching of the diagrams is done, in order to find concordances and to construct a synthetic sequence of soot films for each archaeological level. Graphical matching is made by sets of dilatation/contraction of the diagrams. The growth rates of the crusts are different at several points of the vault and walls, but these are subjected to the same hydrological variations, which affect the whole rock shelter. Accordingly, the carbonates' growth rates are therefore proportional in different points of the vault and walls allowing matching of diagrams by dilating or contracting them (Vandevelde et al., 2017).

Calculation of a statistical index (Barcodes Matching index - BMi) is also possible in order to match the individual sequences of each sample. More than the absolute values of the spaces measured between the films, it is the rhythm of succession of the films represented as bars that matters for graphical matching of barcodes diagrams. This point is the base to develop another way of statistically matching barcodes. The idea is therefore to work on the ratios of the measurements between the successive soot films 


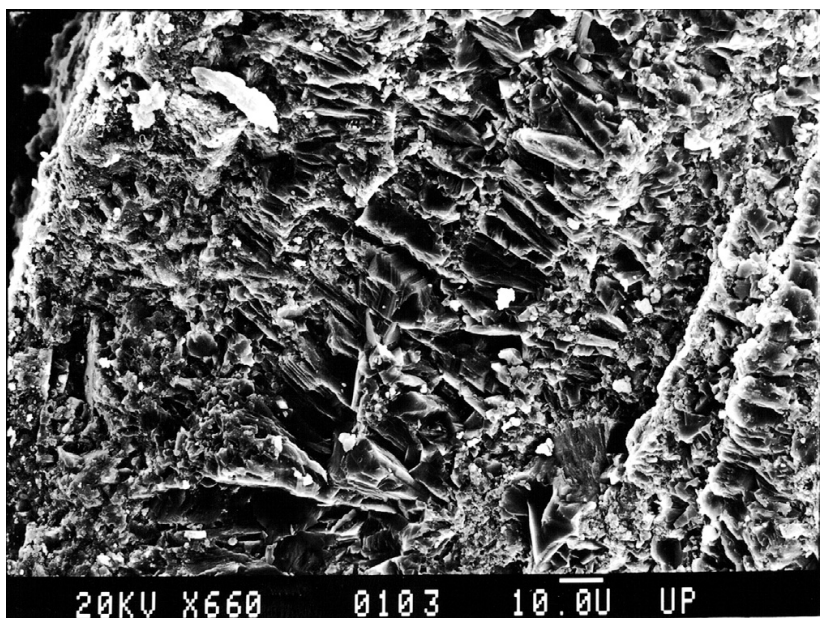

Fig. 8. Succession of micritic (WPL, small crystals) and sparitic (DCL, bigger palisadic crystals) laminae in a parietal carbonated crust from the Balma de la Margineda. Scanning electron microscopy, scale $10 \mu \mathrm{m}$.

(thickness 1 /thickness 2 , thickness 2 /thickness 3 , etc.) and to compare the ratios series two by two. This process has also the advantage of solving the problem of proportionality (Tables 2 and 3 ), which requires contraction/dilatation of diagrams in order to synchronise them, complicating the matching process. Then, it is necessary to shift the two series one on the other in order to see in what position they best correspond to each other (if they match). For each position the BMi is calculated. This index is the sum of the squared differences of each ratio comparison divided by the number of compared ratios.

$B M i=\frac{\sum_{i=1}^{N_{R A B}}\left(R_{A i}-R_{B i}\right)^{2}}{N_{R A B}}$

where $R_{A}$ and $R_{B}$ are ratios of the series $\mathrm{A}$ and $\mathrm{B}$ compared to one another, $i$ the rank of overlapping ratios compared and $N_{R A B}$ the number of compared ratios, which is equal to the range of overlapping ratios $\mathrm{R}$ for the two series $\mathrm{A}$ and $\mathrm{B}$. The closer it is to 0 , the better the correspondence (Table 4). In order to automate the $B M i$ calculations, a macro-command has been developed in spreadsheet software.

Graphically or statistically, when two matching positions are possible for one sample vis-à-vis another, it is the introduction of a third sample, which matches the two other, that confirms one matching position or the other. Note that the $B M i$ is an index informing the operator of probable matching positions of series two by two. It can also be used as a decision-making aid. The idea is to accelerate, help and partially automate the process of matching the samples together. Nevertheless the final decision about matching of series is entrusted to the operator, who is aware of other qualitative information about the samples, influencing the decision.

\section{Results and discussion: from sexy words to scientific concepts, towards a new definition of "occupation floor"}

If one wishes to bring new micro-chronological elements in order to understand the occupations succession in each sedimentary unit and to determine a Minimum Number of Occupations (MNO) per layer, it is necessary to know if the walls and vault are crumbling fast enough for the clastic fragments to be contemporaneous with the layer in which they fall.
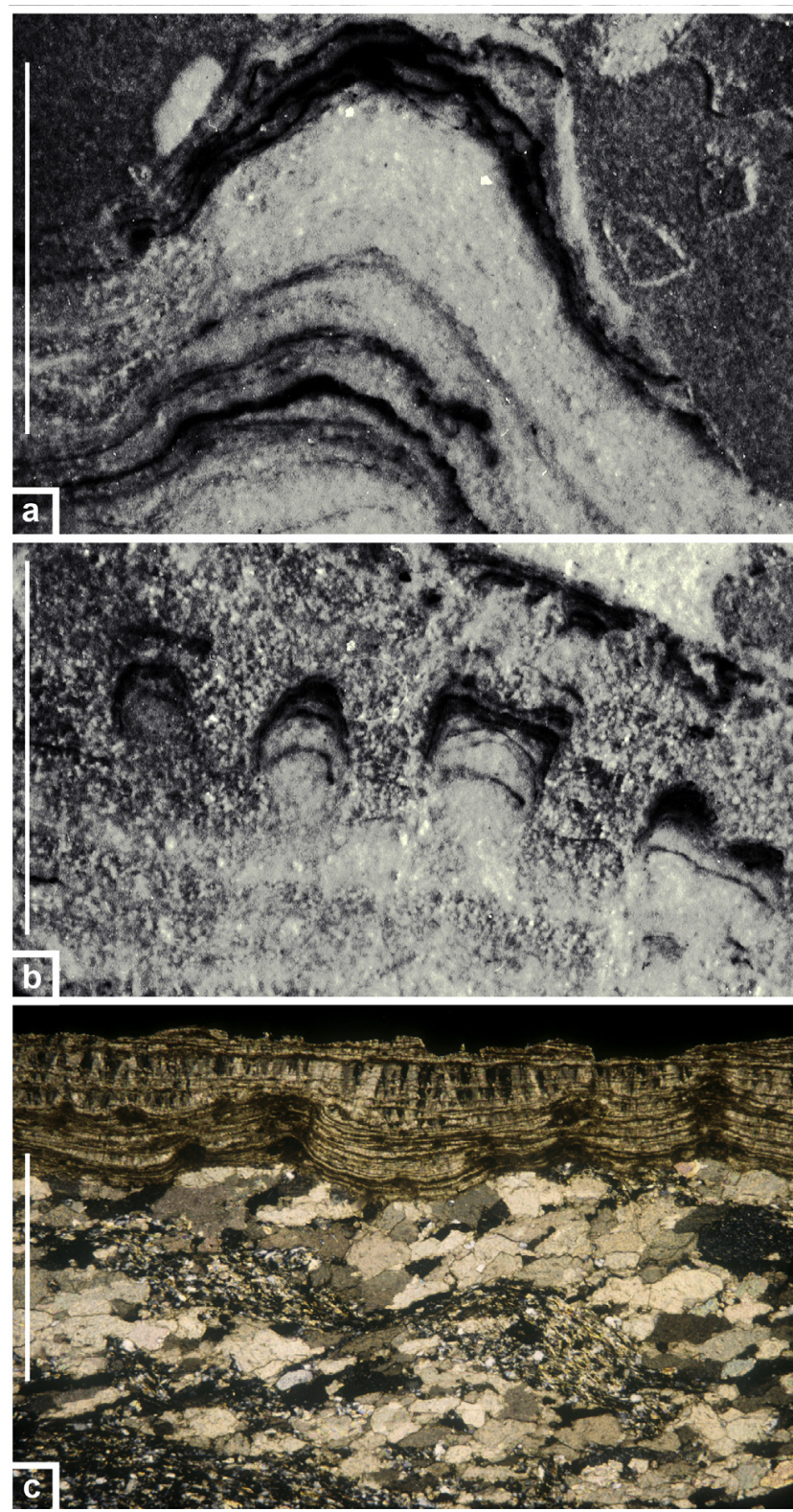

Fig. 9. Parietal carbonated crust trapping soot films, Balma de la Margineda, layer C9. Thin section. a \& b: scale $100 \mu \mathrm{m}$, RL, soot films are preferentially recorded and/or preserved in micro-columns; c: scale $1 \mathrm{~mm}$, XPL.

A sequence of about thirty soot films has been reconstructed at the Balma de la Margineda (Andorra) by synchronising the individual sequences. Schist platelets carrying carbonated crusts on their surface are present in every sedimentary units of the site's filling. But the individual sequences of soot films coming from different units can be easily synchronised, implying that the crusts were formed during the same secular period, during the first occupations (Azilian) of the shelter, and that the walls and vault disintegration extended throughout the overlying levels formation. On contrary, at the Grotte Mandrin the individual sequences generally only overlap within the same sedimentary unit (Figs. 5 and 6). The only overlappings of occupations chronicles from different units occur between adjacent layers (e.g. F and E) and only the end of the underlying chronicle (F) overlaps the beginning of 


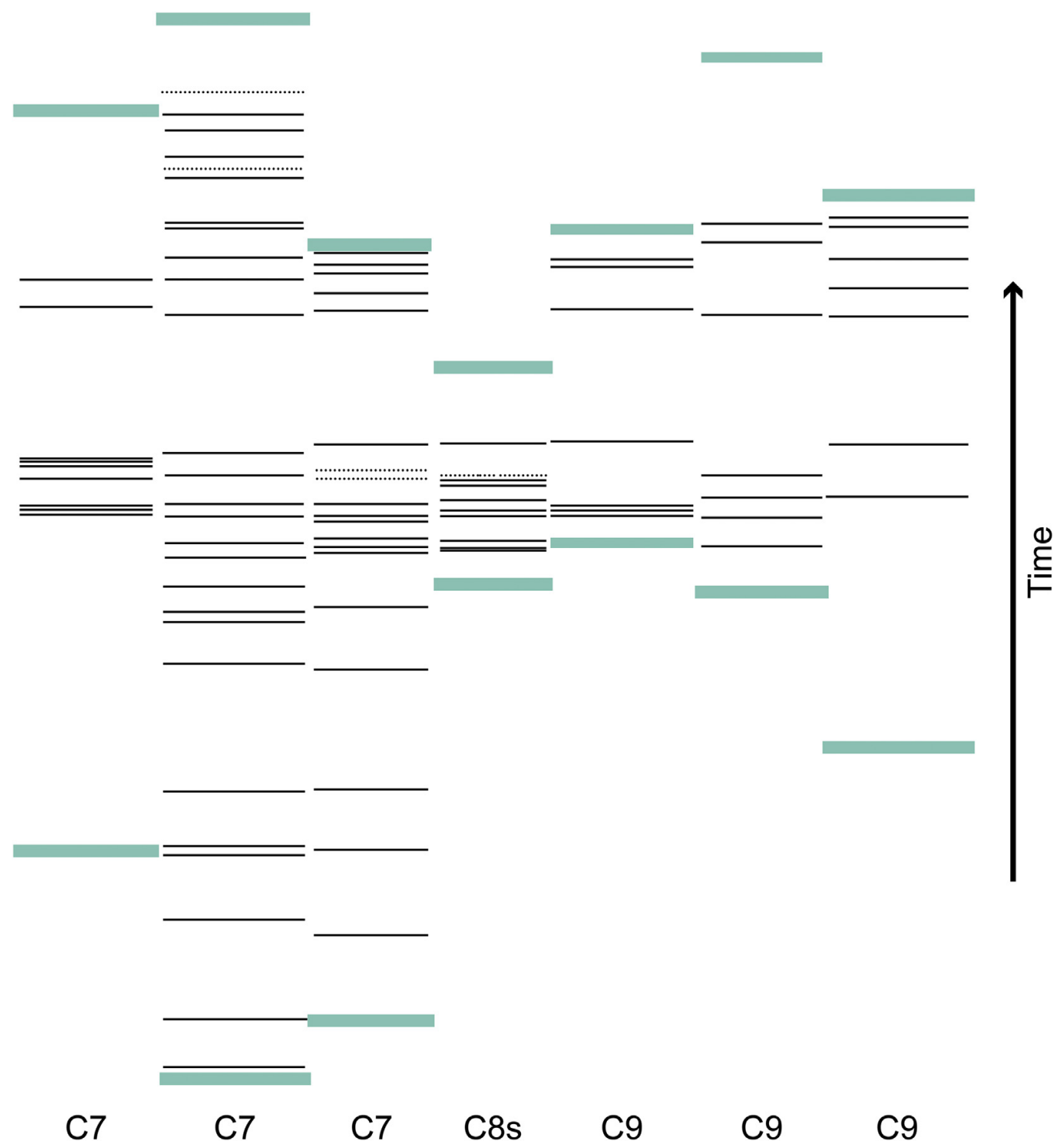

Fig. 10. Synchronisation of individual sequences obtained in the various sedimentary units of the Balma de la Margineda (from layer C9 to C7). The thick lines enclosing the "barcodes" represent the beginning and the end of the carbonated crusts trapping the soot films for each sample. Continuous lines represent soot films and dotted lines symbolize uncertain soot films.

Table 2

Comparison of two theoretical samples (A and B) via the series of thicknesses of carbonates (here fictive) measured between the soot films. The first thickness of each series is that between the first and the second soot films trapped in the crusts of each samples.

\begin{tabular}{lllllllll}
\hline \multicolumn{1}{c}{ Series of thicknesses between soot films } & & & \\
\hline Sample A & 1 & 2 & 4 & 6 & 3 & & \\
Sample B & 9 & 6 & 2 & 4 & 8 & 12 & 6 \\
\hline
\end{tabular}

Table 3

Calculation of the series of ratios (Thickness1/Thickness2; Thickness2/Thickness3; etc.) corresponding to the series of thicknesses between soot films for the samples A and B (see Table 2).

\begin{tabular}{lllllll}
\hline \multicolumn{7}{l}{ Series of ratios (Thickness1/Thickness2; T2/T3; etc.) } \\
\hline Sample A & 0.50 & 0.50 & 0.67 & 2.00 & & \\
Sample B & 1.50 & 3.00 & 0.50 & 0.50 & 0.67 & 2.00 \\
\hline
\end{tabular}

the overlying one (E). This means that the walls and vault crumbled quickly enough for the formation of the parietal carbonated crusts to be globally contemporaneous with the levels in which they are found in the Grotte Mandrin (Vandevelde et al., 2017). Since a 
Table 4

Comparison and calculation of Barcodes Matching Indexes (BMi) between series A and B at several relative positions with a minimum common range of two ratios. This means that a minimum of three thickness measurements between soot films are taken into account, meaning a taking into account of four soot films. In this theoretical case, BMi $=0$ for the position "Test 5 " and the matching is perfect. Nevertheless, with real archaeological data BMi $=0$ is almost impossible, partly due to the budding nature of the crusts, which can cause exaggerated gaps between soot films in some places. So, the closer BMi is to 0 , the better the correspondence.

\begin{tabular}{|c|c|c|c|c|c|c|c|c|c|c|c|c|}
\hline \multicolumn{13}{|c|}{ Comparison and Barcodes Matching indexes (BMi) calculation between series A and B } \\
\hline Test 1 (reference position) & $\begin{array}{l}\text { A } \\
\text { B } \\
\text { differences }^{2} \\
\text { BMi }\end{array}$ & 0.85 & 0.50 & 0.50 & $\begin{array}{l}0.67 \\
1.50 \\
0.69 \\
\end{array}$ & $\begin{array}{l}2.00 \\
3.00 \\
1.00 \\
\end{array}$ & 0.50 & 0.50 & 0.67 & 2.00 & 0.86 & 1.40 \\
\hline Test 2 (shift +1) & $\begin{array}{l}\text { A } \\
\text { B } \\
\text { differences }^{2} \\
\text { BMi }\end{array}$ & 2.90 & 0.50 & $\begin{array}{l}0.50 \\
1.50 \\
1.00 \\
\end{array}$ & $\begin{array}{l}0.67 \\
3.00 \\
5.44 \\
\end{array}$ & $\begin{array}{l}2.00 \\
0.50 \\
2.25 \\
\end{array}$ & 0.50 & 0.67 & 2.00 & 0.86 & 1.40 & \\
\hline Test 4 (shift +3) & $\begin{array}{l}\text { A } \\
\text { B } \\
\text { differences }^{2} \\
\text { BMi }\end{array}$ & 2.01 & 1.50 & $\begin{array}{l}0.50 \\
3.00 \\
6.25 \\
\end{array}$ & $\begin{array}{l}0.50 \\
0.50 \\
0.00 \\
\end{array}$ & $\begin{array}{l}0.67 \\
0.50 \\
0.03 \\
\end{array}$ & $\begin{array}{l}2.00 \\
0.67 \\
1.78 \\
\end{array}$ & 2.00 & 0.86 & 1.40 & & \\
\hline Test 6 (shift +5$)$ & $\begin{array}{l}\text { A } \\
\text { B } \\
\text { differences }^{2} \\
\text { BMi }\end{array}$ & 0.78 & 1.50 & 3.00 & 0.50 & $\begin{array}{l}0.50 \\
0.50 \\
0.00\end{array}$ & $\begin{array}{l}0.50 \\
0.67 \\
0.03 \\
\end{array}$ & $\begin{array}{l}0.67 \\
2.00 \\
1.78 \\
\end{array}$ & $\begin{array}{l}2.00 \\
0.86 \\
1.31 \\
\end{array}$ & 1.40 & & \\
\hline Test 7 (shift +6) & $\begin{array}{l}\text { A } \\
\text { B } \\
\text { differences }^{2} \\
\text { BMi }\end{array}$ & 0.67 & 1.50 & 3.00 & 0.50 & 0.50 & $\begin{array}{l}0.50 \\
0.67 \\
0.03\end{array}$ & $\begin{array}{l}0.50 \\
2.00 \\
2.25\end{array}$ & $\begin{array}{l}0.67 \\
0.86 \\
0.04\end{array}$ & $\begin{array}{l}2.00 \\
1.40 \\
0.36\end{array}$ & & \\
\hline Test 8 (shift +7) & $\begin{array}{l}\text { A } \\
\text { B } \\
\text { differences }^{2} \\
\text { BMi }\end{array}$ & 0.97 & 1.50 & 3.00 & 0.50 & 0.50 & 0.67 & $\begin{array}{l}0.50 \\
2.00 \\
2.25 \\
\end{array}$ & $\begin{array}{l}0.50 \\
0.86 \\
0.13 \\
\end{array}$ & $\begin{array}{r}0.67 \\
1.40 \\
0.54 \\
\end{array}$ & 2.00 & \\
\hline
\end{tabular}

platelet found for example in E can carry on its surface a soot film sequence deposited during the previous (F) and contemporary $(\mathrm{E})$ layer formation, but not during posterior occupations (D), it was possible to establish, not a secular occupations chronicle in the shelter, but occupations chronicles corresponding to the deposition of each sedimentary unit.

Each archaeological level presents its own rhythm of soot film succession. Occupancy phases (sets of occupations separated by long hiatus or differentiated by different occupational rhythms) are sometimes identifiable and it is possible to precisely quantify the MNO in the rock shelter for each archaeological level and for the whole stratigraphy. Even if we do not yet precisely control the time recorded by these carbonated crusts, as it could be the case from classical speleothems with DCL-WPL doublets generally proved to be annual, it was possible to obtain MNO per layer in the Grotte Mandrin: 13 archaeological levels are transformed into a minimum of 273 occupations (Table 5) of which at least 243 for the 12 Palaeolithic levels. More particularly, there are at least 6 occupations for the Protoaurignacian level (B1); MNO of 61 is recorded for the Post-Neronian II (B2-C2) and MNO of 30 for the Post-Neronian I (D); Neronian (E) counts at least 18 occupations; MNO of 21 is recorded for the rhodanian Quina Mousterian (F) and MNO of 108 for the deepest part of the stratigraphy. Such a micro-chronological
Table 5

Minimum Numbers of Occupations (MNO) established for each archaeological levels of Grotte Mandrin site. The numbers in brackets are taking into account the uncertain soot films (dotted lines on the diagrams). See Vandevelde et al. (2017) for more details on the building of occupations chronicles, especially for the one that spreads from layer $\mathrm{F}$ to $\mathrm{E}$ and the one that spreads from layer $\mathrm{C}$ to level B1.

\begin{tabular}{lllll}
\hline Layer & Level & Period & MNO & \\
\hline A & & Neolithic & $29(30)$ & Upper Palaeolithic \\
B & B1 & Protoaurignacian & 6 & Middle Palaeolithic \\
& B2 & Mousterian (Post-Neronian II) & 9 & \\
& B3 & Mousterian (Post-Neronian II) & 14 & \\
C & C1 & Mousterian (Post-Neronian II) & $38(41)$ & \\
& C2 & Mousterian (Post-Neronian II) & & \\
D & & Mousterian (Post-Neronian I) & $30(34)$ & \\
E & & Neronian & $18(20)$ & \\
F & & Mousterian (Rhodanian Quina) & $21(23)$ \\
G & & Mousterian (Ferrassie) & $12(19)$ \\
H & & Mousterian & $8(9)$ & \\
I & & Mousterian & $70(82)$ & \\
J & & Mousterian & $273(26)$ & \\
\hline Total & A to J & &
\end{tabular}

resolution is fundamental for the archaeologist since it has, for example, serious consequences on the interpretations of space studies. 
Indeed, a new perception of "occupation" emerges. An "occupation floor" or "archaeological floor" is defined by Bordes (1975) and Binford (1982) as a recognisable surface on which Palaeolithic human lived for a sufficiently short period of time for the position of artefacts to tell something about their activities (Bordes, 1975, pp. 139); it is the result of a single short-term occupation, which "can be defined as the uninterrupted use of a place by participants in a cultural system" (Binford, 1982, pp. 5); it would therefore be in reality a purely theoretical object. Bordes (1975) had already stressed the fact that the archaeological layers are cumulative units. At the Grotte Mandrin, a "floor" has been identified, by the heterogeneous horizontal dispersion of the material (blocks and artefacts) and identification of anthropic structures in layer $\mathrm{E}$ : a reused fireplace and two concentric stone and big bones circles are structuring the space; areas were also freed of limestone chips and blocks; note that the dispersal of limestone chips is homogeneous in the shelter in other archaeological layers. Also concentration of special artefacts can be seen in special areas, like for example concentration of hundreds of micro-points around the fireplace, and rejection areas outside the stone structure. Position of artefacts and blocks tell something about human activity and show an organisation of space, but even in this case where a "floor" is recognisable, it appears that multiple occupations $(\mathrm{MNO}=18$ ) have nevertheless succeeded each other. Although some micromorphological studies reveal different occupational surfaces within the same layer (see e.g. Boivin, 2000; Matthews, 2005; Goldberg et al., 2009; Aldeias et al., 2012), it is of course impossible to isolate them during the excavation (Brochier, 1999; Aldeias et al., 2012). In view of the micro-chronological studies carried out on the sooted carbonated crusts at the Balma de la Margineda and the Grotte Mandrin, it seems clear that what is observed archaeologically in the case of an "occupation floor" is not the theoretical object defined above. It is rather a recognisable surface on which Palaeolithic human lived, where one can hope to deduce from the position of the artefacts something about their activities, but which delivers intimately associated artefacts resulting from several occupations. This may correspond to repeated uses of a place by participants in the same cultural system whose spatial organisation remains generally the same during each occupation. Note that we are here discussing "occupation floors" and not "constructed floors" as it can be found for example in urban archaeology. The constructed unit has a construction time and then a time of use. The unit of occupation consists of traces of human occupations and therefore results from the use of space.

The archaeological layers and floors must therefore be considered as cumulative units, testifying of multiple occupations. We could just as well have spoken of "palimpsests", since this term is widely used in archaeological literature. However it originally designates "a manuscript or piece of writing material on which later writing has been superimposed on effaced earlier writing". In the archaeological field, this concept corresponds to many definitions: it can refer, in its strictest and most literal form, to the phenomena in which traces of ancient activities have disappeared, apart from the most recent ones; it can also refers to "cumulative" palimpsest, in which all traces are preserved but so reworked that they can not be separated into their original components. Note that there are also "spatial palimpsests", "temporal palimpsests" or "palimpsests of meaning" and each one has its own definition (Bailey, 2007). It is evident considering the numerous connotations accompanying it that the use of this word is singularly lacking in clarity and even in utility. What remains a powerful metaphor in literature turns into a concept that is plural and not explicit enough. It would be better to do without it in (geo)archaeological disciplines in favour of more precise terms on the deposition and postdepository history. The "cumulative" term describes much better the geoarchaeological reality (Brochier, 1999). The minimum archaeological unit is the object that the archaeologist cannot divide further, whatever its thickness (centimetric or decimetric). In any case, it must be considered cumulative as long as data of a different nature than archaeological (in general geological) come to prove the contrary. Note that this is true for prehistoric archaeology but also for urban archaeology, where a minimum archaeological unit can possibly be divided in short-term events.

These remarks must not push to abandon spatial studies, but to realise them only after defining the object of study, in order to avoid misleading in the interpretations. Aware of (and not ignoring) this issue, some studies already show a real concern in doing it. Some new approaches are developed in order to work on reducing the observation scale and on looking for the smallest archaeological unit to analyse. These minimum archaeological units remain cumulative but are well defined, allowing realisation of relevant spatial studies. See for example the works undertaken at the Abric Romaní, where the temporal dimension and the possibility that the assemblage may be the result of different occupational events have been considered (Carbonell i Roura (Dir.), 2012; Chacón et al., 2015; Gabucio et al., 2016; and Rivals' and Romagnoli's papers in the present volume). What may first appear as limiting spatial studies provides in fact much more information than if the cumulative "problem" had been eluded. If the minimum archaeological unit studied is proved to be the result of a single occupation, then "palethnological" study on a freeze-frame can be done. But when a spatial organisation is seen as in most case on a cumulative unit (e.g. Grotte Mandrin's layer E) then it is the dynamic of a repeated use of space that is studied.

For example in Grotte Mandrin, the micro-chronological study of sooted concretions allows to precisely define what a Minimum Archaeological Unit is (here the archaeological layers, or when there are, the levels of occupations defined within the archaeological layers) by identifying the MNO that contributed to its formation. But mostly, if it was not cumulative we would have a solely soot film with the identification of the season of occupation. If it would have been the case for the Neronian (level E) of Grotte Mandrin, a palethnological reading of the spatial organisation of a unique occupation could have been made. But in fact the Neronian level is cumulative and this actually allows going much further. There are 18 occupations minimum and we can observe a particular spatial organisation in this archaeological level. We cannot therefore conclude that this bone is contemporaneous (at the occupation timescale) with that point, but it can be seen that the same spatial organisation has been preserved over the 18 occupations. A recurrence can therefore be identified and precisely defined. Moreover, events can potentially be identified within this repetition: beyond the occupational event, numerous lithic or faunal refitting can also make possible the understanding of articulation of areas (linked or not) at a precise time.

The study of past human societies may prove to be much richer when we have culturally homogeneous and cumulative ensembles, because it can be done with a high temporal resolution and through time.

\section{Conclusions}

At the Balma de la Margineda, it was possible to count more than thirty occupations for a unique level of Azilian age. The soot films are at all times associated with the micritic laminea (WPL). It suggests that the occupations always took place during the same period, as furthermore sustained by zooarchaeological study (cementochronology, ichthyology): the Capra ibex's mating season (Le Gall, 2008; Martin, 2008). We see here the interest of coupling 
this micro-chronological approach developed on sooted concretions with other complementary high temporal resolution methods, such as classical seasonality studies or approaches like the one developed in this volume by F. Rivals.

At the Grotte Mandrin, a Minimum Number of Occupations was established for each one of the archaeological levels, from Middle Palaeolithic to the first European Upper Palaeolithic (levels J to B1) and for a Neolithic layer (A).

In both cases, the high MNO established for each archaeological level invited us to rethink the concept of occupation, and of "occupation floor" (also "living floor" and "archaeological floor"), which reveals to be in its first acceptance a purely theoretical object. Therefore, spatial studies must not be abandoned but undertaken carefully. By losing the illusion of studying freeze-frames we gain the opportunity not only to identify but also to study recurrences, and even more, to analyse and precisely define them. The analysis of their singular, repetitive structure is of high value with regard to past logistics and cultures.

An obvious application of the many potentials of study of these sooted concretions concerns the problem of the origin of use of fire. Since the use of fire in a rock shelter or a cave may leave traces in the parietal concretions, presence of several soot films in the same carbonated crust can constitute a strong argument of the repeated use and thus control of this technique. Recurrent wild fires may also leave their trace in speleothems (Desmarchelier et al., 2004). It is then the repetition, the frequency, the location of the films in the DCL-WPL doublets and the presence of humans on the site, that make it possible to identify the anthropogenic nature of the fires. Indeed, it is difficult to imagine a repetition of wild fires during the seasons of hydric excess. On the contrary, it is a plausible scenario during the dry seasons. If soot films are not located only in WPL, the anthropogenic nature of the fires leaving traces of soot is highly probable.

It is also possible to directly date the soot for recent periods or directly date the concretion for recent and older periods. Tests are on going on the Grotte Mandrin's samples.

Analyses of organic chemistry of soot deposits are also currently on going. The smell of tar is always present in the case of the Grotte Mandrin. It emerges very clearly when one scratches these coatings. This means that the organic matter has been preserved in calcite and that its analysis could enable us to specify its nature.

Beyond the establishment of a MNO at the Grotte Mandrin, determination of the season of each occupation and therefore the study of the rhythms of occupations for each cultural group, are on the agenda. Occupations may be seasonal, as in the Balma de la Margineda, but it is not necessarily the rule. Ethnographies on hunter-gatherer groups can help archaeologists, who study past societies that also have hunter-gatherer economy, to draw some hypotheses about past societies. Ethnographies can guide research of several competing hypotheses, necessary premise for any validation. Nevertheless, the validation of hypotheses must only be based on archaeological evidences and ethnological analogies must be banned (Testart, 2006, 2012). In the same way that Boivin (2000) demonstrated the cyclicity of floor and wall plastering through ethnographic comparisons, studies on the mobility of human groups with a huntering-gathering economy and their ways of occupying rock shelters or caves in a territory will have to be carried out in order to create an updated frame of reference. This will allow listing of plausible hypotheses (within the meaning of Testart, 2006, 2012) about mobility schemes of each cultural group studied at the Grotte Mandrin, since the study of occupations rhythms draws new archaeological potentials regarding time and space.

Research perspectives on sooted concretions are numerous and promising. It is a powerful micro-chronological tool to answer fundamental archaeological questions. It seems that many sites contain this type of material and, in view of the results obtained at the Balma de la Margineda and the Grotte Mandrin, these sooted concretions may open a new path to the understanding of past human societies, thanks to the recording of events with high temporal resolution.

\section{Disclosure and conflicts of interest}

No conflict of interest to declare.

\section{Acknowledgements}

We would like to thank Benjamin Lambert (G. L. Conception) for the adaptation of DATAWALD Software (LnSeq module) to our material. High magnification observation has been done at the Service d'Imagerie et de Microscopie - SIMO in the Maison Archéologie et Ethnologie (MAE) in Nanterre, France. Long-term researches in Grotte Mandrin have been made possible due to two decades of financial supports of the French Service Régional de l'Archéologie (SRA) of the Rhône-Alpes region. Finally, we would like to thank Francesca Romagnoli, Yoshihiro Nishiaki, Florent Rivals and Manuel Vaquero for organising the T10-Q session of WAC8 on "Multidisciplinary approach in the definition of highresolution events to interpret past human behaviour".

\section{References}

Aldeias, V., Goldberg, P., Sandgathe, D., Berna, F., Dibble, H.L., McPherron, S.P. Turq, A., Rezek, Z., 2012. Evidence for Neandertal use of fire at Roc de Marsal (France). J. Archaeol. Sci. 39, 2414-2423.

Aubouin, J., Brousse, R., Lehman, J.-P., 1996. Précis de géologie. In: Pétrologie, vol. 1. Dunod ed, Paris.

Baddeley, G., 1994. Earthwatch in mammoth cave national park Kentucky, USA. Nargun - J. Vic. Speleol. Assoc. Inc 27, 7-17.

Bailey, G., 2007. Time perspectives, palimpsests and the archaeology of time. J. Anthropol. Archaeol. 26, 198-223.

Baker, A., Smith, C.L., Jex, C., Fairchild, I.J., Genty, D., Fuller, L., 2008. Annually laminated speleothems: a review. Int. J. Speleol. 37, 193-206.

Bárta, J., 1961. Zur Problematik der Höhensiedlungen in den slowakischen Karpaten. Acta Achaeol. Carpathica 2, 5-39.

Benington, F., Melton, C., Watson, P.J., 1962. Carbon dating prehistoric soot from salts cave, Kentucky. Am. Antiq. 28, 238-241.

Binford, L.R., 1982. The archaeology of place. J. Anthropol. Archaeol. 1, 5-31.

Boivin, N., 2000. Life rhythms and floor sequences: excavating time in rural Rajasthan and Neolithic Catalhoyuk. World Archaeol. 31, 367-388.

Bordes, F., 1975. Sur la notion de sol d'habitat en préhistoire paléolithique. Bulletin de la Société préhistorique française. Comptes Rendus Des. Séances Mens. 72, 139-144.

Brady, J.E., Veni, G., 1992. Man-made and pseudo-karst caves: the implications of subsurface features within Maya centers. Geoarchaeology 7, 149-167.

Brochier, J.É., 1997. Couches archéologiques ou "sols d'habitat" ? Quelques observations micro-chronologiques dans un abri-sous-roche pyrénéen. In: International Workshop on Archaeological Soil Micromorphology, Basel.

Brochier, J.É., 1999. Couche archéologique, sol archéologique et distributions spatiales : quelques réflexions (géo)archéologiques sur un vieux problème. Geoarqueologia i Quaternari litoral Memorial Maria Pilar Fumanal, pp. 91-95.

Brochier, J.É., 2002. Les sédiments anthropiques : Méthodes d'étude et perspectives. In: Miskovsky, J.-C. (Ed.), Géologie de la préhistoire : méthodes, techniques, applications. Géopré ed. Presses Universitaires de Perpignan, Paris, pp. $453-477$.

Brochier, J.É., 2007. De la sédimentologie à la géoarchéologie. Un demi-siècle de recherches françaises dans les entrées de grottes et les abris-sous-roche. In: Évin, J. (Ed.), XXVIe congrès préhistorique de France. Congrès du centenaire : Un siècle de construction du discours scientifique en Préhistoire. Société Préhistorique Française, Avignon, pp. 31-46.

Brochier, J.É., 2008. Estudi geoarqueològic dels dipòsits tardiglacials de la Balma de la Margineda (Capes de la 6 a la 11). In: Guilaine, J., Barbaza, M., Martzluff, M. (Eds.), Les excavacions a la Balma de la Margineda (1979-1991). Minister d'Afers socials i Cultura, Andorra, pp. 34-52.

(Dir.) Carbonell i Roura, E., 2012. High Resolution Archaeology and Neanderthal Behavior. Time and Space in Level J of Abric Romaní (Capellades, Spain). Springer, New York.

Chacón, M.G., Bargalló, A., Gabucio, M.J., Rivals, F., Vaquero, M., 2015. Chapter 12: neanderthal behaviors from a spatio-temporal perspective: an interdisciplinary approach to interpret archaeological assemblages. In: Conard, N.J., Delagnes, A. 
(Eds.), Settlement Dynamics of the Middle Paleolithic and Middle Stone Age, vol. IV. Tübingen Publications in Prehistory, Tübingen, pp. 253-294.

Chalmin, E., 2006. Caractérisation des oxydes de manganèse et usage des pigments noirs au Paléolithique supérieur. Ph.D. Thesis. Université de Marne-la-Vallée, France.

Clottes, J., 1995. L'originalité de la grotte Chauvet-Pont-d'Arc, a Vallon-Pont-d'Arc (Ardeche) (information). In: Comptes rendus des séances de l'Academie des Inscriptions et Belles-Lettres 139e année, pp. 563-568.

Delannoy, J.-J., Gauchon, C., Hobléa, F., Jaillet, S., Maire, R., Perrette, Y., Perroux, A.-S., Ployon, E., Vanara, N., 2009. Karst: from palaeogeographic archives to environmental indicators. Geomorphologie : relief, processus. Environnement 2, $83-94$.

Desmarchelier, J.M., Hellstrom, J., Spate, A., 2004. Constraining Relative Wildfire Frequency in the Australian Alps over the Past 500,000 Years, Using U- Th Dating of Speleothem-encapsulated Soot Layers. Biennial Conference of the Australiasian Quaternary Association, Cradle Mountain, Tasmania, p. 19.

Duncan, S., 1997. Examining early nineteenth century saltpeter caves : an archaeological perspective. J. Cave Karst Stud. 59, 91-94.

Egaña, A.M.C., González, M.L., Irúa, M.V., Abril, F.L.T., Cárdenas, F.D., 2009. Nuevos datos para el estudio de las pinturas rupestres de la prehistoria reciente en el entorno de la Laguna de la Janda. Almoraima 39, 29-44.

Faure, P., 1958. Spéléologie crétoise et humanisme. Bulletin de l'Association Guillaume Budé, pp. 27-50.

Fenenga, F., Riddell, F.A., 1949. Excavation of tommy tucker cave, lassen county, California. Am. Antiq. 14, 203-214.

Gabucio, M.J., Cáceres, I., Rivals, F., Bargalló, A., Rosell, J., Saladié, P., Vallverdú, J., Vaquero, M., Carbonell, E., 2016. Unraveling a Neanderthal palimpsest from a zooarcheological and taphonomic perspective. Archaeol. Anthropol. Sci. 1-26.

Genty, D., Bastin, B., Ek, C., 1995. Nouvel exemple d'alternances de lamines annuelles dans une stalagmite (Grotte de Dinant "la Merveilleuse", Belgique). Speleochronos 6, 3-8.

Genty, D., Baker, A., Barnes, W., 1997a. Comparaison entre les lamines luminescentes et les lamines visibles annuelles de stalagmites. Comptes Rendus Acad. Sci. Sci. de la terre des Planètes 325, 193-200.

Genty, D., Dauphin, Y., Deflandre, G., Quinif, Y., 1997b. Exemples de particules d'origine anthropique piégées dans les lamines de croissance de stalagmites intérêt pour la reconstitution des environnements humains anciens [Examples of anthropogenic particles trapped into stalagmite growth laminae - interest for the study of prehistoric human activity.]. Quaternaire 8, 149-157.

Genty, D., Vokal, B., Obelic, B., Massault, M., 1998. Bomb 14C time history recorded in two modern stalagmites - importance for soil organic matter dynamics and bomb 14C distribution over continents. Earth Planet. Sci. Lett. 160, 795-809.

Gibbons, D.A., 2003. An Environmental Assessment of Bermuda's Caves. Ph.D. Thesis. Office of Graduate Studies of Texas A\&M University, United States of America.

Goldberg, P., Miller, C.E., Schiegl, S., Ligouis, B., Berna, F., Conard, N.J., Wadley, L. 2009. Bedding, hearths, and site maintenance in the middle stone age of sibudu cave, kwazulu-natal, South Africa. Archaeol. Anthropol. Sci. 1, 95-122.

González, M.E.I., Martínez, P.F., 1998. Hallazgos rupestres en torno a la antigua ruta de Zeugma a Edessa, in: romanización y Cristianismo en la Siria Mesopotámica. Antig. Crist. (Murcia) XV, 119-127.

Górny, A., Gradziński, M., Pazdur, M.F., 1994. Stalagmity z czarno zabarwionymi laminami z jaskini ciemnej (dolina prądnika)/stalagmites with black laminae in the jaskinia ciemna (dolina prądnika, southern Poland). Przegląd Geol. 42, 270-271.

Gradziński, M., Górny, A., Pazdur, A., Pazdur, M.F., 2003. Origin of black coloured laminae in speleothems from the Kraków- Wieluń Upland, Poland. Boreas 32, $532-542$.

Gradziński, M., Hercman, H., Nowak, M., Bella, P., 2007. Age of black coloured laminae within speleothems from Domica cave and its significance for dating of prehistoric human settlement. Geochronometria 28, 39-45.

Gradziòski, M., Hercman, H., Nowicki, T., Bella, P., 2001. Dark coloured laminae within speleothems as an indicator of the prehistoric man activity: case study from Domica cave (Slovakia). In: Preliminary Results. 13th International Congress of Speleology, 4th Speleological Congress of Latin America and Caribbean, 26th Brazilian Congress of Speleology, Brasilia DF, pp. 263-267.

Gramly, R.M., 1975. Meat-feasting sites and cattle brands: patterns of rock-shelter utilization in east africa. Azania Archaeol. Res. Afr. 10, 107-121.

Greer, J., Greer, M., 1997. Dark zone rock art in surratt cave, a deep cavern in central New Mexico. In: Freers, S.M. (Ed.), American Indian Rock Art, pp. 25-40.

Guilaine, J., Martzluff, M., 1995. Les excavacions a la Balma de la Margineda (19791991). Minister d'Afers socials i Cultura, Andorra. Edicions del Govern d'Andorra.

Guilaine, J., Barbaza, M., Martzluff, M., 2008. Les excavacions a la Balma de la Margineda (1979-1991). Minister d'Afers socials i Cultura, Andorra. Edicions del Govern d'Andorra.

Higham, T., Douka, K., Wood, R., Ramsey, C.B., Brock, F., Basell, L., Camps, M., Arrizabalaga, A., Baena, J., Barroso-Ruiz, C., Bergman, C., Boitard, C., Boscato, P. Caparros, M., Conard, N.J., Draily, C., Froment, A., Galvan, B., Gambassini, P., Garcia-Moreno, A. Grimaldi, S., Haesaerts, P. Holt, B., Iriarte-Chiapusso, M.-J. Jelinek, A., Jorda Pardo, J.F., Maillo-Fernandez, J.-M., Marom, A., Maroto, J., Menendez, M., Metz, L., Morin, E., Moroni, A., Negrino, F., Panagopoulou, E., Peresani, M., Pirson, S., de la Rasilla, M., Riel-Salvatore, J., Ronchitelli, A., Santamaria, D., Semal, P., Slimak, L., Soler, J., Soler, N., Villaluenga, A., Pinhasi, R., Jacobi, R., 2014. The timing and spatiotemporal patterning of Neanderthal disappearance. Nature 512, 306-309. Supplementary information.

Ishihara-Brito, R., Guerra, J., 2012. Chapter 4 : Windows of the earth: an ethnoarchaeological study on cave use in Suchitepequez and Solola. Guatem. AMCS Bull. 23, 51-60. Heart of Earth: Studies in Maya Ritual Cave Use.

Knezevic, R., Zikovic, R.G., 2011. Analysis of the condition and development opportunities of cave tourism in primorsko-Goranska county. Turizam 15, 11-25.

Kopacz, J., Skalski, A.W., 1976. Excavation of the cave system in the towarn mountains near częstochowa. Archeol. Pol. Wroc. aw 17, 163-175.

Kučera, B., 1964. Krasova morfologie a vyvoj Ardovske jeskyne v Jihoslovenskem krasu/the karst and the development of Ardovo Cave in South-Slovakian Karst. Ceskoslovensky Kras. 16, 41-56.

Kunský, J., 1939. Ardovská jeskyně ve Slovenském krasu. Rozpr. Ii. tríídy Ceske Akad. $21,1-12$.

Lachenal, T., Rucker, C., 2009. L'aven de la Mort de Lambert (Valbonne, AlpesMaritimes) et les dépôts de vases en grotte à l'âge du Bronze en France méridionale. In: Bonnardin, S., Hamon, C., Lauwers, M., Quilliec, B. (Eds.), Du matériel au spirituel: réalités archeologiques et historiques des "dépots" de la Préhistoire à nos jours. XXIXe rencontres internationales d'archéologie et d'histoire d'Antibes. APDCA, Antibes, pp. 223-237.

Lauritzen, S.-E., Løvlie, R., Moe, D., Østbye, E., 1990. Paleoclimate deduced from a multidisciplinary study of a half-million-year-old stalagmite from Rana, northern Norway. Quat. Res. 34, 306-316.

Le Gall, O, 2008. Els peixos de la balma de la Margineda (Capes de la 7 a la 10). In: Guilaine, J., Barbaza, M., Martzluff, M. (Eds.), Les excavacions a la Balma de la Margineda (1979-1991). Minister d'Afers socials i Cultura, Andorra, pp. 532-539.

Macintosh, N.W.G., 1952. Paintings in beswick creek cave, northern territory. Oceania 22, 256-274.

Martin, H., 2008. Recerca sobre l'estació de captura de les cabres pirinenques pels azilians de la balma de la Margineda. In: Guilaine, J., Barbaza, M., Martzluff, M. (Eds.), Les excavacions a la Balma de la Margineda (1979-1991). Minister d'Afers socials i Cultura, Andorra, pp. 524-530.

Martínez-Pillado, V., Aranburu, A., Yusta, I., Stoll, H., Arsuaga, J.L., 2010. Clima y ocupaciones en la Galeria de Estatuas (Atapuerca, Burgos) en los ultimos 14.000 años: relatos de una estalagmita. MUNIBE Antropol.-Arkeol. 61, 89-102.

Martínez-Pillado, V., Aranburu, A., Arsuaga, J., Ruiz-Zapata, B., Gil-García, M., Stoll, H., Yusta, I., Iriarte, E., Carretero, J., Edwards, R., Cheng, H., 2014. Uppe Pleistocene and Holocene palaeoenvironmental records in Cueva Mayor kars (Atapuerca, Spain) from different proxies: speleothem crystal fabrics, palynology, and archaeology. Int. J. Speleol. 43, 1-14.

Matthews, W. 2005. Micromorphological and microstratigraphic traces of uses and concepts of space. In: Hodder, I. (Ed.), Inhabiting Çatalhöyük: Reports from the 1995-99 Seasons. McDonald Institute for Archaeological Research, Cambridge pp. 355-398.

Mötefindt, H., 1914. Die Diebeshöhle bei Uftrungen. Kr. Sangerhausen. Z. für Ethnol. 46, 646-661.

Okkonen, J., 2007. Archaeological investigations at the sámi sacrificial site of ukonsaari in lake inari. Fennosc. Archaeol. XXIV, 29-38.

Perrette, Y., Delannoy, J.-J., Genty, D., Destombes, J.-L., Quinif, Y., 1997. Enregistrement de l'activité charbonnière dans les spéléothèmes de Choranche (Vercors, France). In: 12th Congress of Speleology, Switzerland, vol. 1, pp. 61-64.

Petránek, J., Pouba, Z., 1951. Pokus o datování vývoje jaskynĕ Domice na základĕ studia tmavých zon v krápnících a sintru (Dating of the development of the Domica Cave, based on the study of the dark zones in the travertine formations). Sborník Ústředního Ústavu Geol. 18, 245-272.

Slimak, L., 1999. Pour une individualisation des Mousteriens de type Quina dans le quart sud-est de la France ? La Baume Neron (Soyons, Ardeche) et le Champ Grand (Saint-Maurice-sur-Loire, Loire), premieres donnees. Bull. la Societe Prehistorique Fr. 96, 133-144.

Slimak, L., 2004. Les dernières expressions du Moustérien entre Loire et Rhône Ph.D. Thesis. ESEP UMR 6636 - MMSH, Université de Provence, Aix-en-Provence, France.

Slimak, L, 2008. The neronian and the historical structure of cultural shifts from middle to upper palaeolithic in mediterranean France. J. Archaeol. Sci. 35, 2204-2214.

Slimak, L., Pesesse, D., Giraud, Y., 2006. Reconnaissance d'une installation du Protoaurignacien en vallée du Rhône : implications sur nos connaissances concernant les premiers hommes modernes en France méditerranéenne. Comptes Rendus Palevol 5, 909-917.

Solecki, R.S., 1979. Contemporary Kurdish winter-time inhabitants of Shanidar cave, Iraq. World Archaeol. 10, 318-330.

Striebel, T., 1996. Höhlen im Gebiet der Stadt Blaubeuren, VDHK-Jahrestreffen 1996 Blaubeuren 150-171.

Stylow, A.U., Mayer, O., 1996. Los TITVLI de la Cueva Negra: lectura y comentarios literario y paleográfico. In: Antigüedad y cristianismo: Monografías históricas sobre la Antigüedad tardía, El balneario romano y la Cueva Negra. Antig. Christ. (Murcia), vol. XIII, pp. 367-406.

Testart, A., 2006. Comment concevoir une collaboration entre anthropologie sociale et archéologie ? À quel prix ? Et pourquoi ? Bull. la Société préhistorique française 103, 385-395.

Testart, A., 2012. Avant l'histoire. L'évolution des sociétés, de Lascaux à Carnac. Bibliothèque des Sciences humaines. ed. Gallimard, Paris.

Valde-Nowak, P., Alex, B., Ginter, B., Krajcarz, M.T., Madeyska, T., Miękina, B. Sobczyk, K., Stefański, D., Wojtal, P., Zając, M., Zarzecka-Szubińska, K. 2014. Middle paleolithic sequences of the ciemna cave (prądnik valley, Poland): the 
problem of synchronization. Quat. Int. 326-327, 125-145.

Vandevelde, S., Brochier, JÉ., Petit, C. Slimak, L. 2017. Establishment of occupations chronicles in Grotte Mandrin using sooted concretions: rethinking the Middle to Upper Palaeolithic transition. J. Hum. Evol. 112, 70-78.

Verheyden, S., Baele, J.-M., Keppens, E., Genty, D., Cattani, O., Cheng, H. Lawrence, E., Zhang, H., Van Strijdonck, M., Quinif, Y., 2006. The Proserpine Stalagmite (Han-sur-Lesse Cave, Belgium): preliminary Environmental
Interpretation of the Last 1000 Years as Recorded in a Layered Speleothem. Geol. Belg. 9, 245-256.

Watson, P.J., Yarnell, R.A., 1966. Archaeological and paleoethnobotanical investigations in salts cave, mammoth cave national park, Kentucky. Am. Antiq 31, 842-849.

White, J.P., 1965. Archaeological excavations in new Guinea: an interim report. J. Polyn. Soc. $74,40-56$. 